\title{
Shakespeare's Merry Wives of Windsor in an Egyptian Adaptation: A Study in Cultural Appropriation
}

\section{Abstract}

The theory of adaptation is particularly applicable when examining M. Enani's Merry Wives, an adaptation of Shakespeare's Merry Wives of Windsor. Enani deals with Shakespeare's play as a main source of his play, trying to create a new Egyptian milieu for the events to suit the Egyptian reader and audience. Adaptation and appropriation are a practice of intertextuality. Enani translated the play into Egyptian Arabic. Enani felt that it would not be successful unless it was Egyptianized. To add local atmosphere, he titled his work Merry Wives, reformulated the names of the characters and changed the setting to an Egyptian suburb, Maadi, like Windsor Park in Shakespeare's play. Enani gave the characters native Egyptian names in place of foreign names. The entirety of Enani's play is written in Egyptian Arabic. Similar to Shakespeare's play, Merry Wives is a farce comedy about the middle class, containing also characters both above and below it, but the events as a whole reflect the power and force of the middle-class. It is a comedy using physical humor and situational irony.

Key Words: Adaptation - Egyptian Arabic Appropriation-Intertextuality- Farce Comedy. 
Shakespeare's Merry Wives of Windsor in an Egyptian Adaptation:A Study in Cultural Appropriation

\section{تمصير مسرحية "زوجتان مرحتان من وندسور" لشكسبير : در اسة فى التطويع الثقافى}

ملخص البحث

تتطبق نظرية الاقتباس بشكل معين على مسرحية" زوجات مرحات" لمحمد عنانى

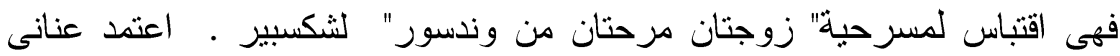
على مسرحية شكسبير كمصدر أساسى لمسرحيته الا أنه وضع أحداثها فى بيئة ونئة

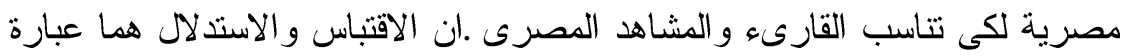

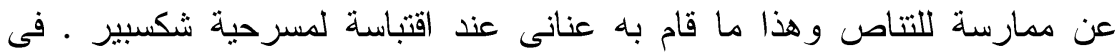

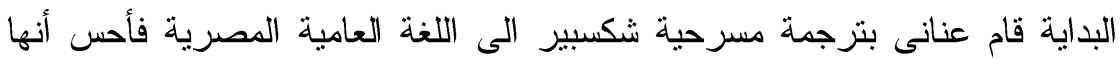
ستكون مسرحية ناجحة اذا تم تمصبرها .ولكى يخلق هذا الجو المصرى للمسرحية

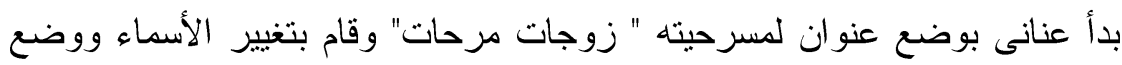

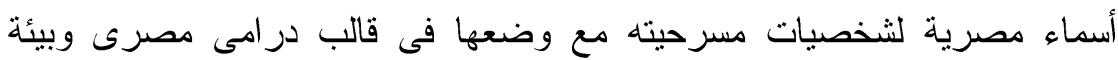

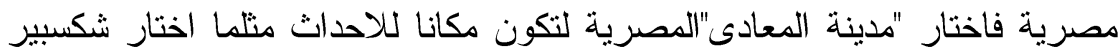
مدينة وندسور كمكانا لاحداث مسرحيته. كتب عنانى مسرحيتة المقتبسة باللغة العامية المصرية مشابها شكسبير فى كونها كوميديا هزلية تدور أحداثها حول الطبقة المتوسطة متضمنة شخصيات أخرى فوق وتحت هذه الطبقة أيضا لكن أحداث

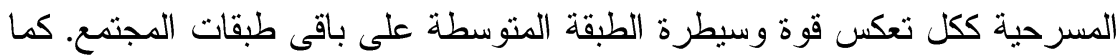
تعد مسرحية عنانى" زوجات مرحات " مسرحية كوميدية نستخدم أساليب الفكاهة بالحركات البدنية و السخرية الموقفية مثلما فعل شكسبير فى مسرحيته. كلمات مفتاحية: الاقتباس - العامية المصرية - الاستدلال - التناص -

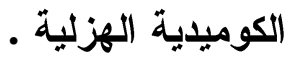




\section{Shakespeare's Merry Wives of Windsor in an Egyptian Adaptation: A Study in Cultural Appropriation}

\section{Hoda Soliman Mohammed, Lecturer in English and Comparative Literature, , Department of English, Faculty of Arts, Menoufya Unviersity.}

While adaptation itself has been around at least since the Greeks, Greek drama being adaptations of popular tales and myths, theory of adaptation starts by studying adaptation as adaptation. This means that it examines adaptations as announced and extended revisitations of prior or adopted work. The reason is that the notion of adaptation implies a focus on, and a study of, both the product and the process of creation.

That curious double fact of the popularity and yet consistent scorning of adaptation is where $A$ Theory of Adaptation begins its study of adaptation as adaptations; that is, not only as autonomous works. Instead, they are examined as deliberate, announced,and extended revisitations of prior works. Because we use the word adaptation to refer to both a product and a process of creation and reception. (Hutcheon and O'Flynn, 2013, xvi) 


\section{Shakespeare's Merry Wives of Windsor in an Egyptian}

Adaptation:A Study in Cultural Appropriation

Theory of Adaptation "explores the continuous development of creative adaptation, and argues that practice of adapting is central to the story-telling imagination..." (Hutcheon and O'Flynn, 2013), "a bit like redecorating." (Uhry, Alfred, 2013). After all, according to novelist Philip Pullman in The Guardian, "theatre is much less high-minded than those who keep a watchful eye on its purity; the stage has always cheerfully swiped whatever good stories were going." (Pullman 1). Burroughs (1991) writes that "the work of other writers is one of a writer's main sources of input, so don't hesitate to use it, just because somebody else has an idea doesn't mean you can't make that idea and develop a new twist for it. Adaptations may become quite legitimate adoptions."

The theory of adaptation is particularly applicable when examining M. Enani's Merry Wives, an adaptation of Shakespeare's Merry Wives of Windsor. As early as 1976, Wimsatt says

Any art work is something which emerges from the private, intentionalist realm of its maker's mind and personality; it is in a sense... made of intentions and intentionalistic material. But at the same time, in the moment it emerges, it enters a public and a certain sense an objective realm; it claims and gets attention fron an audience; it invites and receives discussion, 


\section{Dr. Hoda Soliman Mohammed}

about its meaning and value, in

an idiom of inter-subjectivity and conceptualization.

Enani deals with Shakespeare's play as a main source of his play, trying to create a new Egyptian milieu for the events to suit the Egyptian reader and audience. "Yet adaptation can also constitute a simpler attempt to make texts 'relevant' or easily comprehensible to new audiences and readerships via the process of proximation and updating. This can be seen as an artistic drive in many adaptations of so-called 'classic' novels or drama for television and cinema. Shakespeare has a particular focus, a beneficiary even, of these 'proximations' or updating." (Sanders, 2006, P. 19). Most theories of adaptation are based on the concept that the new literary work deals with the adapted one as the core, which is reflected in different media and genres.

Most theories of adaptation assume, however, that the story is common denominator, the core of what is transposed across different ways and, I would add, through different modes of engagement - narrating, performing, or interacting. In adapting the story argument goes, "equivalences" are sought in different sign systems for the various elements of the story: its themes, events, world, characters, motivations, points of 
Shakespeare's Merry Wives of Windsor in an Egyptian Adaptation:A Study in Cultural Appropriation

view, consequences, contexts, symbols, imagery, and so on.

(Hutcheon and O'Flynn, 2013, 10)

Adaptation and appropriation are a practice of intertextuality which means that "all texts invoke and rework other texts in a rich and ever-evolving cultural mosaic. The impulse towards intertexataulity, and the narrative and architectural bricolage that can result from that impulse, is regarded by many as a central tenet of postmodernism." (Allen, 2001)

The term adaptation is "a transpositional practice" meaning an act of re-vision by "casting a specific genre into another generic mode." The process of adaptation involves a kind of offering commentary on the source text. "This is achieved most often by offering a revised point of view from the 'original', adding hypothetical motivation, or voicing the silenced and marginalized." (Sanders, 2006, 18)

Robert Weimann $(1988,433)$ defines "appropriation as an activity... not closed to the forces of social struggle and political power or to acts of historical consciousness." This means to "examine in detail the specific impulses and ideologies, personal and historical, that are at play in various acts of adaptation and appropriation. It seems useful therefore to start by unpacking in some detail what we might mean by such umbrella terms and considering the different modes and methodologies of adaptation, as well as its varying disciplinary manifestations." (Sanders, 2006, P. 18)

It is clear that appropriation "frequently affects a more decisive journey away from the informing source into a 


\section{Dr. Hoda Soliman Mohammed}

wholly new cultural product and domain. This may or may not involve a generic shift, and it may still require the intellectual juxtaposition of (at least) one text against another that we have suggested is central to the reading and spectating experience of adaptation." (Sanders, 2006, P. 26)

Merry Wives of Windsor is the fifteenth Shakespearean play that is mostly acted and presented to the audience as an interesting play not only in England but throughout the world. Shakespeare is the most influential writer, and the most important playwright of English literature and Renaissance. His plays seem to have imprinted on the entire corpus of Western literature and culture. Merry Wives, written in 1597, is in its essence a "play of intrigue" built on weaving intrigues and counter intrigues. It is based on the ancient thought which is old as literature and poetry itself. It is "harming and harmful: or pushing the cunning back to its source" which brings relief to the audience.

Enani translated the play into Egyptian Arabic in the early 1980s based on its first publication, the quarto edition in 1602. Enani felt that it would not be successful unless it was Egyptianized. To add local atmosphere, he titled his work Merry Wives, reformulated the names of the characters and changed the setting to an Egyptian suburb, Maadi, like Windsor Park in Shakespeare's play. Enani gave the characters native Egyptian names in place of foreign names. The entirety of Enani's play is written in Egyptian Arabic. Enani says (2008):

I here present two texts of one play to the Arabic reader. The 
Shakespeare's Merry Wives of Windsor in an Egyptian

Adaptation:A Study in Cultural Appropriation

first represents the final form of the play, the second is the form of the play after having been abridged by the author during his time and after I adapted it to an Arabic play taking place in Egypt. (my trans.)

Merry Wives of Windsor is a middle-class play in its setting, themes, subject matter, and outlook. It can be classified as a farce drama using jokes and gags for a comic tone throughout, that leads to the play's ultimate spirit of reconciliation. Shakespeare's Merry Wives of Windsor was in its turn taken from Ser Giovanni Fiorentio's Italian play Il Pecorone, in 1558, and resembles it in its main plot. The plot and also the subplot go back in their colouring to ancient Roman comedy and medieval farce. Though Merry Wives of Windsor is about the middle class, it contains also characters both above and below the middle class, but ultimately the whole events function to demonstrate the assimilating power and force of the middle class.

This play was firstly performed in London 1597 at a feast of the Order of the Garter attended by Queen Elizabeth herself, who had asked Shakespeare to write a play on the character or Falstaff, the main character of Shakespeare's play Henry $I V$, Part I. So Shakespeare put aside Henry IV, Part 2, to write Merry Wives of Windsor including many characters who appeared in Henry IV, Part 2 such as Pistol, Mistress Quickly, Bardolph Shallow, and Nim. Rawe (1702) says that the Queen was so well pleased with the admirable character of Fastaff in Two Parts of Henry the Fourth that she 


\section{Dr. Hoda Soliman Mohammed}

commanded him to continue it for one play more, and to show him in love. This is said to be the occasion of writing The Merry Wives of Windsor. The main character Falstaff and his entourage were supposedly close friends of Prince Henry, later Henry $\mathrm{V}$, that adds a monarchal touch to the suburban events of the play of Merry Wives of Windsor.

The original text of the play survives in two different versions, the first one is The First Quarto (1602) which is a reconstruction from memory by the actors of the first parts in the first performance of the play, but the other one is The First Folio (1623) which is printed from an authorial manuscript.

That the play is a comedy
of manners appears in the
contrast between the folio text, of
3018 lines, and the quarto text, of
1618 lines. The difference is
largely in material not necessary
to the story-sketches of
character and manners, such as
the lesson in Latin conducted by
Sir Hugh, with Quickly's
comments. (Gajowski and
Rackin, 2015).

Modern critics reassessed The Merry Wives of Windsor previously thought to be one of Shakespeare's weakest plays - as one of the most entertaining, cheerful, and ebullient of Shakespeare's comedies, characterized by a vigorously imaginative artistic style that is full of energy and excitement. 
Shakespeare's Merry Wives of Windsor in an Egyptian Adaptation:A Study in Cultural Appropriation

The Merry Wives of
Windsor (c.1597-98) has been
reassessed by modern critics who
have found the play to be a more
interesting work than earlier
commentators. The plot centers
on the attempts of Falstaff to
seduce the two "merry wives,"
the Mistresses Ford and Page.
When Falstaff's efforts are
discovered, the wives form an
elaborate scheme designed to
humiliate him.

(Gajowski and Rackin, 2015).

The play's popularity on the stage based upon its fast-paced action, physical humor, situational irony, and unconventional characters. The characters reflect unconventional and slightly strange views and behaviour. Michael W. Shurgot (2001), in his review of Lillian Grog's 2001, remarks that the production of the play was a "three-hour marathon of sight gags, pratfalls, and petty stuff". William Green (2002) reviews the staging of the play, directed also by Lillian Groug, declaring that the production achieved Shakespeare's aim of the play "writing a play to entertain", praising the happy mood and setting, colorful costumes, and musical effects. That production appears to have been musical and somewhat unique. Russell Jackson (2003) remarks that "the setting conveyed the confident rhetoric of the period". 


\section{Dr. Hoda Soliman Mohammed}

From the very beginning of the play, mostly middle-class characters are introduced in their small town milieu, directly introducing the main struggles of this comedy, which is the main thrust of Elizabethan comedy, usually marriage: in this case, the marriage of Slender and Anne Page that is the main aim of Shallow and Evans. The focus is also on the relationship between couples who are already married such as the pairs of Page and Ford and their wives. Falstaff is a knight and of a high rank than most of Windsor's natives, but he abuses his position to torment the locals, forming with his entourage the first maligned group in the play. In fact, there are three main groups of people in the play: the first, as mentioned above, being Falstaff and his entourage; the second is made up of public figures that have earned ridicule, namely, Shallow, Evans, and Caius. Evans (the Welsh clergyman) speaks with an accent that the English can't bear, Shallow is a foolish character of misplaced authority as he is an incompetent man of the law, and Caius is a Frenchman who speaks in fragments of French and English. The third group is formed by Mistresses Page and Ford and their husbands. These two women are the "merry wives" of the title as they are described as irrepressible and inseparable. Their project is to humiliate Falstaff in order to teach their husbands that wives can be both merry and honorable at one time.

As is common in a comedy of intrigue, Mistress Quickly, "everyone's messenger", plays the citizens of Windsor against one another as she knows all the secrets kept by each of them. She has a double-dealing way as she performs various errands to get money as, for example, she promises the three suitors seeking Anne's hand to help each one. This use of a lower-class servant to manipulate their masters not 


\section{Shakespeare's Merry Wives of Windsor in an Egyptian}

Adaptation:A Study in Cultural Appropriation

only reminds us of the commedia dell'arte, but keeps the stakes low: the intrigue remains centered on love and marriage (rather than politics as in Shakespeare's more serious plays).

The side of the comedy of manners also appears in the scene where Mistress Page says, "Sir Hugh, my husband says my son profits nothing in the world at his book. I pray you, ask him some questions in his accidence" [Latin grammar] (Merry Wives, 4.1.11-13). To prove that he is teaching him very well, Evans asks William Page some questions that Quickly misunderstood to be sexualized slang because of Evan's mispronunciation that mangles most of the words. Shakespeare adds a comic scene based upon linguistic humor as Evans is talking to William, teaching him, but because of Evans' mispronunciation of Latin words and Quickly's mispronunciation of Latin words as English slang plays for laughs providing a sense of humor.

At the end of the convoluted plot, despite the different kinds of conflict between townspeople throughout the play, the end and the conclusion are fully inclusive as Falstaff, the scapegoat, instead of being dismissed from the final scene as a final punishment, he is invited to the feast watching the Pages' humiliation at the revelation of the array of suitors and their plots against each other.

Although the play involved separating out anyone who isn't a middle-class or a local, at the end all the characters are come together, moreover, everyone becomes a middle-class or local. For example, the Host made fun of Evans and Cauis who plotted against him later. Page and his wife refused 


\section{Dr. Hoda Soliman Mohammed}

different suitors for Anne, Falstaff was tormented and humiliated. But finally, they all come together. It is Shakespeare's way of portraying the middle-class as a warm welcoming group that is able to forget, forgive, and embrace outsiders into their communities. "Good husband, let us everyone go home, And laugh this sport O'er by a country fire; Sir John and All." (Merry Wives, 5.5. 218-220)

Merry Wives of Windsor is Shakespeare's most middle class play, and on of his most farcical that its comic intrigues create a jovial tone that transcends hierarchies and provides a kind of reconciliation between upper and lower-class characters drawing them together into the burgeoning middle class. It is a kind of drama where the formation of the middle class is dramatized out of disparate social tensions. The main plot is reflected through the behavior of title characters Mistress Page and Mistress Ford who are the playful but virtuous wives focusing on their main point of view that wives can be merry and faithful at the same time: they can lead rich and interesting lives without betraying their two prosperous husbands, a fact that Mr. Page understands but Mr. Ford doesn't. At the same time, the love and marriage of Fenton, (a man of higher birth but less money) and Anne affirms romantic love as a kind of social assimilator enabling individuals to create new social categories around their romantic relationships.

The play is rich in vitality and continous dynamics. It often causes laughter - often laugh-out-loud -through the humorous language in the play. It is also full of stagecraft, as the scene of hiding Simple at Dr. Caius' house by Mistress Quickly. Another example is when Ford disguises himself as Brooke to discover Falstaff's intention regarding his wife. 


\section{Shakespeare's Merry Wives of Windsor in an Egyptian Adaptation:A Study in Cultural Appropriation}

These tricks are some of the methods which playwrights to create dramatic irony. The release of laughter leads to a happy ending. Comedy is achieved, harmony and comfort come back to the self. This is the indication that life wins in the end.

The tone of middle-class is emphasized through the social network of the community that takes a negative view of anyone with origins outside Windsor. For example, Evans is mocked for his foreign accent, Slender looks like a fool because of his pretensions, Shallow seems fool as his authority is based upon the monarchy, and Caius, the French doctor, is similarly teased for his external roots and source of authority.

The hostility of the locals to the aristocracy appears in two way; First in Page's rejection of Fenton's request for marrying Anne as he suspects Fenton as having financial desires for Anne that is untrue. The resistance to the aristocracy lies in the repeated abuse of the lusty Falstaff who becomes at the end, the scapegoat for the whole town to mock as a result of his financial motivation trying to seduce the Mistress. Finally, the successful marriage between Fenton and Anne is a kind of great reconciliation of the middle class and aristocracy.

Shakespeare uses middle-class tone, written in prose, produced in proverbs and clichés; slender and Mistress Quickly depend on cliché. Quickly also misunderstands and misinterprets words through the play such as hearing sexual innuendo in Latin conjugation and declensions, "throwaway insults against foreigners show a kind of casual linguistic 


\section{Dr. Hoda Soliman Mohammed}

ethnocentrism, which reaches its heights in the ridicule of fragmented English and unusual pronunciation of Evans and Caius". (Cohen, Waller, 1997).

The title of the play enhances the primacy of the women's roles, it is literally the story of the Merry Wives as Mistress Ford and Mistress Page are in a continuous conflict because of gender. They show that men should not be jealous, they should trust their wives. Mistress Ford's problem is her jealous husband, Mistress Page's problem is different as her husband is unjealous but she and him have each chosen a different suitor for their daughter Anne to marry who manages to show herself to be truly the only woman who is free, she manages to create a companionable marriage like that of her parents, but against their will. Discussing the role of women in Merry Wives, Sandra Clark (1987) says that "the women of Merry Wives work to destroy stereotypical conceptions of women with their wit," which "operates as a means of obtaining revenge for women against the insults offered to their honesty by the male vices of lust and jealousy, and also as a way of restoring to the community the values of order and domestic stability."

The play reflects some flaws that characters should overcome; Ford's flaw is his jealousy of his wife, which appears justified when his wife invites Falstaff to her house, only not for the reason Ford imagines. Such suspicions weaken their relationship, so he must learn to be jealous of a woman who may be merry and fun-loving, but who would never dishonor him. After knowing that Falstaff was at his house twice, Mistress Ford admits her scheme to humiliate Falstaff. Ford discovers that he was wrong to doubt his wife, deciding to humiliate Falstaff just for good measure. 


\section{Shakespeare's Merry Wives of Windsor in an Egyptian}

Adaptation:A Study in Cultural Appropriation

Page seems to be a kinder husband than Ford as he trusts his wife but his relationship with his wife Mistress Page is weakened when they don't listen to their daughter Anne, ignoring her desires in favor of financial support that they prefer to love. At the end, they learn the lesson accepting their daughter's choice for her happiness.

In Shakespeare's works, England tends to be for the most part represented by kings or soldiers, but for the first time in Merry Wives of Windsor, England is represented by real people such as Englishmen who make fun of foreigners' use of language, various groups who try to humiliate and make fun of the others, and everyone seems to be plotting against someone else, but at the end everyone is alive, and going together to celebrate a wedding. The play is closely related to our modern world as there are happy women, happy wives, jealous husbands, and young lovers. The Merry Wives of Windsor is a comedy taken from life as it is based upon real issues such as jealousy, love, and deceit. The wives are having the task of seduction, men deceiving them with false identity. So the play is a great example of everyday life regarding perspective, the words, humorous imagination, the action and reality of the wives, and men's jealousy. It is a wonderful, uplifting play in which Shakespeare did not use women as tools to ridicule but to give them the same display of confidence that he gives to his male characters. "The Merry Wives of Windsor has proven irresistible on the stage; the play was popular with its original audiences and remains a favorite with modern audiences as well." (Gayowski and Racking, 2015).

The "Merriness" of the title refers to ability to impliedly produce "playhood and entertainment" in the text. The court 


\section{Dr. Hoda Soliman Mohammed}

are having a merry vacation at Windsor, that little town exemplary of the English countryside. It creates an atmosphere suiting the merry tale besides the hearth in cold winter. Such a type of merry tales was dear to the heart of the middle class, whose members used to prefer comic tales, in the $16^{\text {th }}$ century, with their pranks, or acts of deceit. A wife, for instance, may succeed in hiding her infidelity, while a shrewd girl may manage to escape the snares of a promiscuous priest. As in the Arabian Nights, such tales are popular folklore.

The central tale of The Merry Wives belongs to the "fabliau" genre, the promiscuous tales of the middle Ages. However, such tales used to be "merry" in the age of Shakespeare, being the forerunner of the early modern age when wives began to slough off old fetters and enjoy autonomy, shrewdness and quick-mindedness.

As a play of revenge, the playwright had to employ such sources so as to complement what we may call "the social history" which is a sine qua non for an integrated picture for the author and the audience alike. Now, we have a highly bizarre form of revenge; one of the bourgeoisie; it is a subject-matter for comedy, not tragedy, for its trivial ends. From the very beginning, the thin thread of revenge is found, knitting the components of the plot and its apparently unrelated actions.

Falstaff, for instance, admits his stealing the deer and faces more and more accusations, all of which bring about no penalty, but tension throughout the play; they herald more actions leading to the central plot when Nym (whose very name alludes to looting) disobeys the orders of Falstaff. This 


\section{Shakespeare's Merry Wives of Windsor in an Egyptian}

Adaptation:A Study in Cultural Appropriation

is a comic pasticcio of the conventional revenge plays. These characters may attain some success in the play's middle class milieu.

Next we have another avenger, Dr. Caius, the French physician who decided to average himself against Evans for the latter's effort to marry Ann Page to Slender. Caius calls Evans for a duel, while people of Windsor await such a silly challenge. The hotelier decides to avoid the duel by setting different places for it. Both Evans and Caius, embittered by the hotelier's trick, decide to avenge themselves against him; after their reconciliation. Now we have a revenge of a different sort; an invisible plot on the part of Evans and Caius.

Ford was another avenger who visited Falstaff, though disguised, to learn his intent. He decided to avenge himself against Falstaff, who thought for a while that he, too, had his retaliation. He would avenge himself against Ford for trying to tempt his wife. This deliberate transformation of the theme of revenge into a comic form implies satirizing the destructive revenge per se.

Metamorphosis of the idea of revenge per se is strongly related to the very idea of metamorphosis which Shakespeare owes to Ovid in his Metamorphoses. In the final scene, Falstaff is disguised as hunter Herne, with his two great horns. His monologue teems with images of metamorphosis. Ovid is certainly the source, though in a popular comic image suiting Shakespeare's play and middle class. Acteon, too, is a hunter turned into an antelope by Diana, in Greek mythology. Acteon, now an antelope, fled his own dogs which chased and tore him into pieces. In Twelfth Night, 


\section{Dr. Hoda Soliman Mohammed}

Shakespeare uses Acteon as a symbol of the forlorn lover chased by his passions, though Falstaff faces charges of being a procurer because horns allude to one's being a procurer. However, the true Acteon is Falstaff. At his first appearance, he is a hunter and robber of deer, then turns into hunter and robber of women for his need of money, as well as his vanity; he understood the ovation and courtesy of the two women as a call for promiscuity. The two women, like Diana, were unaware of that. Hence, they imitated Diana in her revenge.

The climax of the play, in the final scene, has Falstaff with his two antelope horns, voluntarily taking the role of Acteon. Now, he is the victim of the satire and sarcasm of all characters; metamorphosis.

Merry Wives, as critics agree, is Shakespeare's most "farcical" comedy for its farcical movements, though it is not a pure farce thanks to its language. This is evident in Falstaff's poetic images, as well as narration of offstage actions. Farcical actions, in fact, are dramatically employed; they give the playwright an opportunity to present his highly poetic images. An example is Falstaff's being dumped into the river. Shakespeare's language is unique for its waxing and waning style according to the addressee. Falstaff's language is varied, sublime when addressing his servant Robin then lowly when addressing Pistol and Nym as if they were animals. This implies painting, too, as the author "paints" consecutive poetic images; those of the gold shore alluding to the two wives then the metaphor of "hoof". These "overseas" images come in contradiction with the common images of the play which has a middle-class setting. They 


\section{Shakespeare's Merry Wives of Windsor in an Egyptian}

Adaptation:A Study in Cultural Appropriation

are derived from domestic life, common proverbs of the middle class and well-known verses of the Scriptures.

Ford starts out as a stereotype of the jealous person. However, he is a man of action; he does not yield to doubts when Falstaff's statement reaches him through Pistol. He intends to get the truth, which remains incomplete till he discovers his wife's intentions. We, the readers and audience, get amused as we know the truth unknown to Ford. Now we have a character of a comedy not a farce, a character blinded by doubts. But it is able to develop, and this is why actors like to play Ford.

The other character that typically enjoys elements of comic characterization is Slender, whose equivalent in a farce is impossible. Pure comedy is derived from his attempt to woo Anne Page. No wiles or affection are to be found in his extremely "innocent folly", in contrast to the schemes and tricks of others. The idiocy of Slender is inborn and incurable and this is why we pity him, even while laughing at such an idiot. He is just a failed courtier, an ineffectual and shy person who does not raise reluctance against the aristocracy.

The way the two characters of Ford and Slender are drawn in the play makes it a comedy in the first place, with all its farcical elements. The play's nature as a comedy as opposed to a farce is supported by the realism of their actions, as well as the creative usage of motifs of revenge and classical mythology. The highly complicated structure of the play also exemplifies it as a comedy of intrigue. There are two major lines of action; the first is the two wives avenging themselves against Falstaff, while the second is that of the story of Anne Page and her three suitors. The playwright 


\section{Dr. Hoda Soliman Mohammed}

manages to keep both lines separate through the play, until the final scene.

Shakespeare's structure is based on the alternation between these two actions, though interwined into one texture as if they were one "big" action. However, the two main subplots have one important element in common; their theme of revenge. Also, Falstaff and Fenton have one common feature; their status as members of the upper class, though not the aristocracy. This is a middle-class comedy that uses the tools of the farce to achieve its ends. It is characterized by the speed in its movement, language variation among its characters, and the real contradictions among them.

The final noteworthy element in Merry Wives is the structure common at the time of Shakespeare. It is called the over reader: the big party at Windsor Castle. This turns into the external plot or the over plot within which the main plot including Falstaff's and the two wives' takes place. Inside this main plot lies the subplot of the love story between Fenton and Anne Page. The main plot is clearly related to the subplot through unity of the theme of deceit. The subplots are variants of the main plot, just as the sub-themes are variants of the main theme and each theme is represented in actions structurally related to others, while all of which relate to the main plot.

All of these events are inter-related through the idea of playhood, whose end exceeds sheer entertainment. It reinforces values of the closed society against those of the wider society symbolized by the court. Words denoting this playhood vary from entertainment, satire, ridicule to sarcasm, but all of them add to the main plot, structurally 


\section{Shakespeare's Merry Wives of Windsor in an Egyptian}

Adaptation:A Study in Cultural Appropriation

speaking. The structure is integrated in its vitality and flow. It is the "smiling" play or the "cheerful" play from beginning to end. Although it belongs to the play of "intrigue" in its essence, actually hails the values of the middle class and its equality. It was a must to coin these values through a cheerful spirit that guarantees a position to this class. At first glance, the play appears to be a comedy of types, but having prepared us for this, Shakespeare implies extremity in that drama and then he ignores it and concentrates, in turn, on the richness of each character, not as a model of a human defect or stereotype of it but as a human trait subject to change and development.

M.M. Enani declares that "Shakespeare is the only father of modern theatre." (Mahmoud, 2014). Enani has translated around nineteen of Shakespeare's plays; according to him, Shakespeare creates a new perspective for poetic theatrical creativity in addition to his ability in exploring human nature, reflecting it rhetorically. As the father of modern theatre, all modern plays, whether comedy or tragedy, derived from Shakespeare's, Enani says:

Generally speaking, no writer can study modern theatrical drama without going back to Shakespeare who presented new theatre which is completely different from Old Greek theatre, which isn't alive nowadays. (My trans, Mahmoud, 2014) 


\section{Dr. Hoda Soliman Mohammed}

Enani summarizes Shakespeare's theatrical traditions in four main points: the construction of his plays being built upon actions and scenes similar to modern drama, his ability to tackle general human issues, his ability to use political symbolic projection, and the use of slang in his comedies. Enani adapted Shakespeare's Merry Wives of Windsor into Merry Wives, using a native Egyptian setting, Maadi, and writing his comic play in Egyptian vernacular (Egyptian Arabic). Enani's play was staged in 1981 to audience acclaim at the Talia (Avant-Garde) Theater in Cairo.

Similar to Shakespeare's play, Merry Wives is a farce comedy about the middle class, containing also characters both above and below it, but the events as a whole reflect the power and force of the middle-class. It is a comedy using physical humor and situational irony.

In Enani's hands, Evans the priest becomes Wanees the schoolteacher. Enani choses typical Egyptian names for the characters such as Mabrook, Fontas, and Ward, which have the same number of syllables and sound very much like Shakespeare's characters Brooke, Fontas, and Ford acting the same roles in the two plays. Mistress Quickly, everyone's messenger, is changed in the Egyptian play to Mistress Lahloobah, the name which conveys the same meaning in Arabic language. To make the play seem native to Egyptian culture, Enani uses these tricks; for the last one, which is related to English legends, he uses another suitable Egyptian legend or myth, but both lead to the humiliation of Falstaff in Shakespeare's, and of Fontas in Enani's. For the broken English of Dr. Caius, Enani uses Dr. Ghadbaan with his mangled Arabic. 


\section{Shakespeare's Merry Wives of Windsor in an Egyptian}

Adaptation:A Study in Cultural Appropriation

Merry Wives is divided into two acts: the first act starts at Mr. Ramady's Maadi home, in the garden in front of the house. Mr. Ramady and Mr. Wanees are worriedly discussing a vaguely impending visit to their district, Maadi, by the consultant to a high-ranking government official. Mr. Ramady has invited him to dinner tonight. The two men are astonished at this untraditional visit as he is coming suddenly without prior notice.

One of the first things to notice about the play is the time period selected: the Ottoman Empire era, which is at some historical distance from the time the play was written. This is not at odds with the Shakespearean play inasmuch as the original was set in the era of Henry IV. However, the real resemblance of the two plays lies in that although they are both nominally set in the past, the behavior of the characters and their language is clearly belonging to the time the play was written, not to the time the play is supposed to be set in. This deliberate anachronism is not surprising as the Elizabethan era was a time of the rise of the middle class, and the 1980's were also a time when the middle class was still strong and powerful in Egyptian society. Although Merry Wives pays lip service to "the Sultan" and "the Turkish ruler", the drama is very much contemporary. Love as an equalizer and a common denominator to bring together social classes is present in both plays, exemplified by Nourah's marriage and Anne's many suitors. In both cases, a high-born but poor young man wins the hand of the low-born but rich young lady - 'class without brass' meets 'brass without class', coming together in the melting-pot of the middle class. 


\section{Dr. Hoda Soliman Mohammed}

Nourah, Mr. Ramady's daughter, appears. From the beginning of the play, mostly middle-class characters are introduced in their small-town (Maadi) milieu directly introducing the main conflict of this comedy, the visit of the vague Fontas, offering a chance to discuss the marriage of Nourah. The coming focus will be also on the relationship between couples who are already married: Mr. Ramady and Mr. Ward and their wives. Fontas is a man of a higher rank than most of the characters (the inhabitants of Maadi) but he abuses his position to torment the locals, stealing their possessions and money, forming with his entourage the first maligned group in the play.

The second group, the public figures worthy of ridicule, is made up of Wanees, Daheel Naheel, and Dr. Ghadban. The third group is made up of Mistress Zahrah and Mistress Fullah, the wives of the title, whose husbands describe them as irresponsible. Their plan is to humiliate Fontas in order to teach their husbands that wives can be both fun-loving and honorable at once.

The position of Fontas is also related to the deliberate anachronism of Enani's play. In point of fact, the suburb of Maadi did not exist before 1904, and Enani has admitted in interviews that he deliberately introduced this anachronism because the Windsor forest on the Thames seemed ideally matched by the wooded areas on the Nile in the area that was later to become Maadi. In the same vein, Fontas, while nominally a very important person holding the power of life and death over subjects of a country controlled by the Governor, and who might in actual history have had the power to call for these people to be executed, behaves much more like a modern government minister: he is afraid of 


\section{Shakespeare's Merry Wives of Windsor in an Egyptian Adaptation:A Study in Cultural Appropriation}

scandal and feels that being publicly humiliated could cause him to lose his position. Again this anachronism parallels Shakespeare's making the 'historical' characters behave like his contemporaries, in a comedy where the middle-class is the melting-pot.

Getting into the house, Mr. Ramady hears Nourah announcing that her uncle Ward (the husband of Zahrah) is planning to punish Mistress Zahrah as she went out without letting him know. Jealous Ward is forever suspicious that his wife is going to dishonor him.

\section{Nourah: Aunt Zahrah! Uncle Ward wasn't at home when she left... She went out without his permission. Mum says that he is too jealous.}

(My trans.,Merry Wives, Act 1,S. 1)

Zahrah's sister Fullah asks her to stay, as they need her help. Having found out that the household is run by an insanely jealous husband, Zahrah wants to go but Fullah begs her not to go. Nourah comes clean with her aunt, saying, "She is afraid of being hit". (Merry Wives, Act I scene I). Fullah scolds her daughter for insulting her aunt. The men enter, announcing the arrival of Mr. Big himself, the Great Fontas. People gather to welcome him, Ramady is upset because of his sudden visit, and Wanees' worries increase as he predicts that Fontas is coming to investigate something. Wanees keeps repeating that as a teacher nothing is wrong at his 


\section{Dr. Hoda Soliman Mohammed}

school, while Ramady says that they are honorable merchants. They resolve to watch what they say and do until the visit is over. Their behavior is very much like the way a contemporary civil servant or government official would behave in the face of a surprise inspection, lip service to the Ottoman Empire notwithstanding.

Daheel (a Justice) and his nephew Naheel arrive. Daheel discussing his anger at Fontas declaring that he is going to bring him before the court as Fontas's men stole his goat, as well as Naheel's wallet. Ramady asks them not to mention this as Fontas is an important, respectable man.

Ramady: Brothers, for shame! Fontas is an important man with a good reputation ... Excuse me a minute. (Exit.)

(My trans., Merry Wives,Act I, Scene I)

The melting-pot of money and class asserts itself when Wanees, alone with Daheel and Naheel, seeks to distract them from the matter of the goat and wallet by suggesting that he, Wanees, bring suit to Nourah on Naheel's behalf. Daheel, with some class distinction, will have none of it: Nourah, he says, is a farmer's daughter. Wanees affirms the fact that Ramady, Nourah's father, is not a farmer but a prominent merchant whose daughter stands to inherit seven hundred dinars, plus a lot of silver and gold: again the melting-pot of the middle class will bring the judge's son together with the rich tradesman's daughter. However, Naheel reveals his weakness of character, declaring his inability to propose to her without the help of his uncle. 
Shakespeare's Merry Wives of Windsor in an Egyptian Adaptation:A Study in Cultural Appropriation

Naheel: I don't know how to propose.

Wanees: It's quite simple.

Naheel: Uncle must help.

(My trans., Merry Wives, Act I, S.I)

A herald announces the arrival of Fontas, to general consternation.

Herald: Abbas Pasha

Fontas... of illustrious family... admirable in ancestry and appearance! ...Fire and brimstone! Assistant to the Great Ruler!

(My trans.,Merry Wives, Act I, S.I)

Ramady welcomes him effusively, while Fontas, puffed up with his own importance, generously allows Ramady to introduce those present, all gathered in the garden to meet him.

Fontas: (laughing) Do you all live in the garden, then?

(My trans., Merry Wives, Act I, S.I)

Everyone laughs politely at Fontas' weak joke. Asked about Mr. Ward, Zahrah says:

Zahrah: He is coming soon.. I let him know ... when I.. (changing her mind). I mean when I heard you had arrived ... I could not wait and hurried out to welcome you... but he's been out since 


\section{Dr. Hoda Soliman Mohammed}

early morning getting in a

shipment of aubergines.

(My trans., Merry. Wives. Act I, S.I)

The reference to aubergines reinforces the concept that Ward, while wealthy, is not of the upper class and his occupation involves dealing with vegetables, which are symbolic of being 'earthy' and mundane, the opposite of the aristocracy.

On the way in to dinner, Daheel approaches Fontas asking for his goat. Fontas is astonished and the others ask Daheel to stop it but in vain as Daheel and Naheel insists on the goat and wallet that Fontas's men stole: Fontas becomes very angry, and starts to threaten to leave. Ramady tries to calm him down, tempting him with the wonderful dinner they have ready: a well-cooked goat.

\section{Daheel: My goat!}

Everyone goes in to dinner, after which Ramady promises an evening of song and dance. Naheel remains outside, talking to himself about the project of his proposal to Nourah:

Naheel: (alone on stage) Was it really necessary to propose to Nourah today? Is it a suitable time? The consultant's arrived, the goat's gone, the wallet gets stolen, everything's a mess, (searching his pockets) I've lost my joke book! My book of riddles is gone! ... Who said I 
Shakespeare's Merry Wives of Windsor in an Egyptian

Adaptation:A Study in Cultural Appropriation

wanted to propose to her anyway? And even if I did, how would I go about it? Should I tell her about the 700 dinars? What if she doesn't have any silver or gold? No, no, I need to find the right time. (Enter Nourah.) Right, time to go. (He makes to exit. Nourah calls him; he stands transfixed.)

(My trans., Merry Wives, Act I,S. I)

Money rears its head as a recurring theme intertwined with love, as is typical for any dealings with the middle class. Naheel may be a comic figure, but he is given an important line: "Should I tell her about the 700 dinars?" Should money be mentioned in the context of love? The question is posed early on, and only resolved later by Nourah, who reveals herself thematically as a source of reconciliation between love and money - both perennial concerns of the middle class.

Jealous Ward joins them, asking for his wife, accusing her of being inside with Fontas; Ramady corrects him, saying that she is inside with all of them. Ward remains unswayed.

You can say what you please, I won't listen to a word of it. Women are double-dealing. I go to the port to check on the boat, and what do I come home to find? No wife! Vanished! 
After dinner, the Merry Wives, Mistress Zahrah and Mistress Fullah are there. Ramady asks the dancers to come in, and the singer (or Zahrah) to sing.

The singer: O! Selene! once said Lunna to a star who are you?

then? said she smilingly your Lunar light made me stay up at night impressed by your beauty with wistful eyes.

Then a nebula passed, he countenance with a charisma of angle-like halo. The moon calls his star time again

Loo! we have Clouds and long blue night. I'm a moon once only a month my lovers be hold my smile for a single might yours, darling, is a never-to-be-off light $\mathrm{O}$ ! Oasis of safety and propagator of night.

(My trans.,Merry Wives, Act I, S.II)

Fontas, liking the song, asks what it means. Mistress Fullah answers that the song is about constancy: the moon is bright but changeable, while the star - although small - is unchanging. Zahrah, eager to know about what is behind Fontas's visit, tries to ask him. Fontas blusters that he has come at the order of the Turkish ruler in Constantinople to investigate transgressions such as theft and rule-breaking. Zahrah and Fullah try to change the subject by urging him to enjoy the songs and dances.

To calm down the tension, Fullah asks for some Egyptian drink, Zahra insists on offering it herself. Ward, alone with Ramady, expresses his worries regarding Fontas as a womanizer.

Ward : I don't trust this pasha

Ramady:He is a sheer ottoman inspector 


\section{Shakespeare's Merry Wives of Windsor in an Egyptian}

Adaptation:A Study in Cultural Appropriation

Ward: I think he's an impostor

Ramady: All of them are

Ward: We must expose him

Ramady: Not presently. Let's be gentle with him till we know his turn end.

(My trans.,Merry Wives, Act I, S.II)

Zahrah, the merry wife, tells a tale of a fisherman who once caught a mermaid with a beautiful face and long hair. Seeing her tail, he becomes afraid; but she tells him, "It doesn't matter if you have a tail; the most important thing is not to play with it or to use it to harm others." This is a clear example of localization, as an Egyptian expression with this literal meaning — "to play with one's tail" - means to have a sexual relationship. The "tail" refers to the hem of a woman's dress; lifting the hem of her dress is a folk metaphor for having an affair. The archaic expression (referring to a woman) "to have a clean tail," means to be sexually pure. The story serves not only as a warning for Fontas not to seek the wives' favours but as a chastisement for Ward not to be unnecessarily jealous and trust his wife not to hurt him with infidelity. Fontas is unsettled by Zahrah's story, but she tells him it is only a folktale.

Fontas and his entourage (Zaghloul, Zainhom, and Galanf) settle in at a small hotel where they are discussing their theft of Daheel's goat, and Naheel's wallet. Fontas accuses them of dishonest: they stole without sharing with him.

Fontas: Shut up all of you . we are a host . we have to help and love each other at whatever circumstances. Mine are sorties of vanity and pomp. I 


\section{Dr. Hoda Soliman Mohammed}

let you be my co-travellers.Now, you should admit me to your plans. I'm a

generous master of my mom. They too, have to be so.

(My trans.,Merry Wives, Act I, S.3)

The men swear that they ate the goat; as for the wallet, it was empty. Fontas becomes angry.As soon as Fontas declares his need for money, the Host enters, hesitantly asking them to pay the bill; but Fontas, being penniless, responds pompously that he is giving him a present: Fontas' man will work for him to cover the costs of their stay. Fontas, alone with his two men Zaghlool and Zainhom, announces the real reason behind his visit for Maadi. He never goes out hunting or on trips or to investigate; his sole reason is seduce Mr. Ward's wife, Mistress Zahrah, as he has heard that she is a vivacious and spirited woman, controlling her husband's money, his ultimate goal.

Fontas: Good. To put it short, I have his wife as a

target. Lady Zahrah, you know her. I know she is a merry wife . At the bonnet of Ramady, I watched her well . She truly turned out to be such a gentle and soft woman. Hers is diamond-like speech. (Zaghloul and Zainhom show signs of objection).

$$
\text { (My trans.,Merry Wives, Act I, S.3) }
$$

Fontas declares that he is going to send two love letters: one to Mistress Zahrah, and another to Mistress Fullah. Fontas: I've known she controls her husband's money. Now 


\section{Shakespeare's Merry Wives of Windsor in an Egyptian}

Adaptation:A Study in Cultural Appropriation

if she falls in my love as planned, she will be so liberal with me. This is why I've written this letter and this a short poem for her (He takes out two letters of him packet). I've another message for Madame Fullah, wife of Ramady (He laughs!) . She , too, winked at me! (see objections of Zaghloul and Zainhom). Frankly, she was about to devour me with her eyes, looking at my right leg a while, then at my long hair and sometimes at this funny tum.

(My trans.,Merry Wives, Act I, S.3)

Zainhoom and Zaghlool refuse to deliver the love letters to the ladies, saying they will have no part of adultery. Fontas flies into a rage, dismissing them, so they decide to plot to thwart Fontas' plans by revealing them to Ramady and Ward. This exactly parallels Shakespeare's scene where Nym and Pistol refuse to be a part of Falstaff's plans. Egyptian and Elizabethan sexual morality come together to reject extramarital affairs, making this scene appear extremely locally familiar.

Zainhom: I, too, will tell Ward.He is a rose-like man, as his name denotes. Fontas, the big-eared acts the lover of her, causing his wife to be infidel and dishonor him for a few pence from the impecunious Pasha.

Zaghlool: No, the Zeinhom, Never mind. Secrets will be divulge.

(My trans.,Merry Wives, Act I, S.3)

The setting changes to Mr. Ward's house. Mistress Zahrah appears upset, and sends for her sister Fullah to come at once. She has received a love letter from Fontas. 


\section{Dr. Hoda Soliman Mohammed}

Zahrah : ...Never! I can't believe it. We have got rid of messages of love of adolescent foolish days. Now they are posted from the tum of Abbas ibn Fontas.

A very good epic-like poem! Ask me not about my love ...it's inspired by your own beauty.

Now our youth is gone, and love is welcome.

You love humor and I live merriness.

You love warbling the way ladore joyfulness.

Welcome, then, to love, ha, ha, ha.

(My trans.,Merry Wives, Act I, S.4)

Zahrah is astonished.

Zahrah : Impossible. Awfully rude. What's wrong . The dilapidated man acts a lover and horseman! what home I said or done to make him think of seducing me? I just like singing and merriness. I've ever been over in my jesting with him. Well car Fontas. I'll have my score.

(My trans.,Merry Wives, Act I, S.4)

Fullah arrives, also astonished as she has received the same letter from Fontas with the exact same phrasing. The two ladies plan to lead him on till he is humiliated in public. Mistress Fullah says she is ready to do anything that will not harm her honor. They agree to lead him on with false promises.

Zahrah: How. we'll set ate for him and keep on alluring and putting it off till we deplete him.

Fullah: Wonderful

Zahrah: This type of men must be treated this way; the more 


\section{Shakespeare's Merry Wives of Windsor in an Egyptian}

Adaptation:A Study in Cultural Appropriation

you humiliate, the more he gets tempted .

Fullah: Then?

Zahrah: Just help me with my scence.

Fullah: eady for any impish acts, but never cause me dishonor.

(My trans.,Merry Wives, Act I, S.4)

The repeated emphasis on the wives" "honor" is to please the Egyptian audience, to whom female purity, both before and after marriage, are sacrosanct. To create any doubt about this matter would be to lose audience sympathy immediately, which is why the matter of wifely honor is stressed almost to the point of harping on it. This becomes necessary in the scene where Zaghlool and Zainhom follow the two husbands to tell them that Fontas is after their wives. The husbands are astonished, showing two different reactions: Ramady doesn't think that his wife will betray him, but jealous Ward is terribly convinced that his wife is going to dishonor him. It benefits the audience, and prepares them for Ward's comeuppance as well, to have the 'honor' of the wives established emphatically at an early stage.

The two ladies are waiting for Mistress Lahloobah, everyone's messenger, to give her a message to Fontas. The subject of Nourah's suitors comes up: her father Ramady wants to marry her to Naheel, but her mother likes Dr. Ghadban, Lahloobah's master, as a suitor to her daughter. Lahloobah doesn't like the idea, as she loves Dr. Ghadban. She discusses the matter with Ramady and Ward, saying that Nourah will not understand Dr. Ghadban's broken Arabic mixed with Turkish. This is the equivalent of the Welsh clergyman in the original; the foreignness of the language is 


\section{Dr. Hoda Soliman Mohammed}

here exploited for comic reasons and to underscore the foreignness of the suitor as an outsider to the native milieu. Lahloobah tells them about Saadoun, Nourah's lover, in order to arouse Ramady's ire against his daughter. Ward asks Ramady to take care and not to be idiot as no woman can be trusted. Ward calls Ramady a foolish husband as he trusts his wife. This part of the play reflects one of the central themes: the difference between Ward and Ramady is very clear in their responses regarding their wives.

Ward: No Ramady, be vigilant. If the men are idiots, she

isn't . She means attracting our attention to what may take place, or what's already taking place, who knows?

Ramady:Don't be so skeptic. Forgot about her.

Ward: Something may take place, or have already taken place. What wallowed, then?

Ramady: I never care!

Ward: What?

Ramady: If he nearly tries to seduce my wife, it will serve

him right (laugh!)

Ward: Is it such a simple matter?

Ramady:I know my wife, ward.

Ward:You shouldn't speak of her this way.

Ramady:Do you know her better than I do?

Ward:I don't mean this.

(My trans.,Merry Wives, Act I, S.4)

At the small hotel, Mistress Lahloobah arrives wanting to meet Fontas, carrying a message from Mistress Zahrah. Ward will be out next morning and Mistress Zahrah will 


\section{Shakespeare's Merry Wives of Windsor in an Egyptian}

Adaptation:A Study in Cultural Appropriation

expect a visit from Fontas early, taking care to mention Ward, Zahrah's jealous husband. Lahloobah tells him that Fullah also wants to meet him, assuring him that each of the ladies knows nothing of the other's traffic with him. Fontas accepts the invitation, feeling very happy.

Fontas: (Alone on stage). Good Fontas Pasha?

You're still youthful and receive messages

of love (feeling his tum). Thanks my funny

boy. You suit my name of a container.

I'm fat, well. Never mind. A fat lover, No problem.

(My trans.,Merry Wives, Act I, S.5)

Galanf reports that someone called Mabrook is downstairs: it is Ward in disguise. He claims to be in love with Mistress Zahrah, who claims that she is too honorable to cheat on her husband. Ward asks Fontas to seduce her to destroy her honor so that he can blackmail her into an affair with him in future. Ward flatters Fontas that he has power over women, offering him money to destroy Mistress Zahrah's honor. Fontas accepts the money reporting his date with Mistress Zahrah next morning.

Fontas : Listen, Mr Mabrouk. I'll take my time

concerning your money. Secondly,Shake hands.

Thirdly, I'll procure madam Zahrah for you,

if you crave her, Believe my honorable promise.

(My trans.,Merry Wives, Act I, S.5) 


\section{Dr. Hoda Soliman Mohammed}

Mabrook asks if Fontas knows what Ward looks like, but Font as says he doesn't. He asks Mabrook to come to him next day to tell him about his visit with Mistress Zahrah.

Fotas: Why should I know him? I've seen him once only. He's a fool who's piles of money made people like his wife (lanshing) and I, too, like her.

Ward: She isn't so pretty, is she?

Fontas: Who comes . We only need money. Listen Mabrook, I'll humiliate this peasant and procure his wife for you. Come, tomorrow, as agreed, in t evening, to know news. Ward is a donkey and I'll fix him horns.

(My trans.,Merry Wives, Act I, S.5)

Being alone, Ward starts to curse his wife and cannot wait for the next morning to catch his wife with Fontas.

Ward: Impossible. My wife sends for him a message and fixes a date. I can't believe it. O! my wife,

money and honor for him, them he insults and ridicules me ! it isn't enough to kill him. Slaughtering him is a merciful act. Burning him is joyful. No, I'll cut him into pieces for dogs to eat. Cur Pasha, coming soon to see who's the true fool, $\mathrm{O}$ ! fattest idiot.

(My trans.,Merry Wives, Act I, S.5) 


\section{Shakespeare's Merry Wives of Windsor in an Egyptian}

Adaptation:A Study in Cultural Appropriation

The intrigues compound in this section: Ward disguises himself as Mabrook, while Zahrah and Fullah hire Lahloobah to lay a trap for Fontas, even as Ward sets another trap for his wife. Next morning, the Mistresses prepare for the arrival of Fontas, ordering two servants to be ready with a large laundry basket.

Zahrah: In short, you'll remain at kitchen and enter once I call you to carry this basket and go out directly to the Nile besides the tannery Lying next to the bridge. Just dump contents into water. (silence) clear? in the quagmire. it is muddy now, but water will rise after the flood of the Nile. Clear? (My trans., Merry Wives, Act I, S.5)

Mistress Fullah hides, while Mistress Zahrah pretends to be alone. Fontas enters and starts to woo Mistress Zahrah:

Fontas: Morning of roses, like your name, madam Zahrah .

I'm not flirting, I have a heart of gold, cordial love of Pasha's for the lady who excels Pashas.

O! What diamond like eyes and crown-worthy forehead!

(My trans.,Merry Wives, Act I, S.7)

Money rears its head in Fontas' language, which is full of economic metaphors, showing what he is really thinking: "What is in my heart is pure gold," he says, and then says, "Your eyes are diamonds," and goes on to add, "Your forehead should be adorned with a crown." In addition to the 


\section{Dr. Hoda Soliman Mohammed}

many images referring to money and jewels, the comic element in his wooing is underscored by his earnest protestation, "I'm not one for flattery or idle talk."

Fullah appears from her hiding place, announcing that Ward has burst in with men of Maadi looking for a gentleman he believes is in his house. Mistress Fullah suggests that they hide him in the laundry basket and have the servants carry the basket out. Fontas appears and agrees to jump in the basket and is carried away.

Ward, with the other men, arrives, but finds nothing. The two Mistresses are happy to be able to fool both Fontas and Ward. Zahrah intends to teach Ward a lesson, in the tradition of the commedia dell'arte, to stop being jealous. Zahrah and Fullah plan to play more tricks on Fontas to humiliate him and to cure Ward of his jealousy. Discussing happily what will happen to Fontas after being thrown in mud and a vat of dye, the two ladies refer to Fontas' need of moral cleansing. Zahrah: Sure, we have to retry. Let's apologize and rekindle him hope.

Fullah: And let him be closer.

Zahrah:(Laughing) Ok! Fullah. No problem. I'll send him

Lahloobah to set cut at nine tomorrow to make amends.

(My trans.,Merry Wives, Act I, S.7)

Not finding anyone, after searching his house, Ward apologizes to Zahrah in front of the men and she accepts his apology. Ramady invites them all to breakfast, asking them to go hunting in a wood on the River Nile. 


\section{Shakespeare's Merry Wives of Windsor in an Egyptian}

Adaptation:A Study in Cultural Appropriation

Nourah comes out of the house to meet Saadoun, her sweetheart, a handsome and presentable young man. She accuses him of just loving her because of her money. Saadoun declares that he loves her for herself, and if he loved her money it would be because it belonged to her.

Saadoun: How come! I adore you; the soil you walk on; the

food you eat (all of a sudden) and, do you know why

love money? only because it's in your hands.

(My trans.,Merry Wives, Act I, S.7)

Saadoun tells her about his dream of having a big shop on the Nile; he hopes that her father will help them. Ramady refuses their marriage because he suspects Saadoun of just wanting Nourah's money as Saadoun is high born but without money. In another financial metaphor, Saadoun tells Nourah that "While money is important, you are money in yourself; you are money." Hardly the most romantic phrase.

Saadoun: money is surely vital. but (gently) even if

impecunious, nova is Nova. You are Moneta;

your mind, resourcefulness, helpfulness;

everything in you is monetary.

(My trans.,Merry Wives, Act I, S.7)

Interestingly, while the married women are both named after flowers - "Zahrah" is a generic name for flower, while "Fullah" is a variant of jasmine, when it comes to unmarried women, (and adultery), the metaphors used seem exclusively 


\section{Dr. Hoda Soliman Mohammed}

financial. The play seems to be saying that before marriage is the time to focus on all money issues, whereas after marriage the coast is clear for love.

But what of the perennial question: love or money? This is the moment when Nourah - young and representing future relationships - reconciles the two. In a monologue alone on stage, she says:

Nourah: He may be honest? money may beautify women and get admiration of others. Why do I act like an ass; why

should he love me without money? All suitors have a crave of money. I love Saadoon, any may and can't marry any other man.

(My trans.,Merry Wives, Act I, S.7)

The moment when she asks herself, "Why am I so insistent that he love me without money?" paves the way for a valuable insight. "Perhaps money makes a woman attractive, making people fall in love with her." Nourah seems at least partially aware of the false dichotomy of "love versus money" - false because a wealthy person, secure and free from financial hardship, may feel more confident than someone crushed by want, and confidence is known to attract romantic partners. Finally, Nourah says, "well, if all my suitors have their eye on my money, at least I'm in love with Saadoun and I'll never marry anyone else." Pragmatism and realism win the day: Nourah will probably have a better future as she is clear-eyed about finance and relationships. She exemplifies the future of the assimilating middle class. 


\section{Shakespeare's Merry Wives of Windsor in an Egyptian}

Adaptation:A Study in Cultural Appropriation

The issue of Nourah's marriage remains the centre of the events now as Naheel and his uncle Daheel enter. Naheel announces that he's ready to talk to Nourah, having found his joke book, then blathers on about Nourah's money, silver, and gold. As though to emphasize the one-sided and short-sighted plans for Nourah's future, Ramady and his wife enter and discuss the suitors each of them wants for Nourah, ignoring her wishes.

Fontas is in the small hotel lamenting his bad luck and asking Galanf to make him a cup of tea. He is wet after dragging himself out of the Nile after being thrown in with Mistress Zahrah's laundry. In Shakespeare's play, coming back after being thrown in the Thames, Falstaff asks his servant for some wine. To suit the Egyptian culture, coming back after being thrown in the River Nile, Fontas asks his servant for a cup of tea.

Fontas: Good Pasha. You're dumped by mobs into the Nile

like a cat in a bag (Sneezes). If the Thames had been

deeper, I would have drowned or seen mermaid. Oh

God, thanks. It's a good lesson.

(My trans.,Merry Wives, Act II, S.2)

Lahloobah arrives with an apology and a message that Zahrah wants him to visit again when her husband is out hunting. Fontas agrees and Lahloobah exits. Ward (disguised as Mabrook) enters asking how Fontas did with Zahrah. Fontas tells him the story and declares that he has a next date as Zahrah's husband is going hunting. 


\section{Dr. Hoda Soliman Mohammed}

Ward: very good. Am I dreaming? Am I a wake? It's a nightmare, not a dream. wake up ward. You face mudSlinging. This is the end of marriage; of laundry and its basket. He will never escape tomorrow. Where to? I'll seek him at the waterwheel. Black end cur Pasha!

(My trans.,Merry Wives, Act II, S.2) Zahrah and Fullah's scheming to show up Ward's misplaced jealousy, are further supported by Ward's scheming by pretending to be Mabrook, thinking that he is one step ahead of his wife, but he ends up being one step behind Fontas, who is unable to discover the wives' plan for his humiliation. Again Fontas arrives at Zahrah's house, and again Mistress Fullah arrives asking if Zahrah is alone? Fontas hides. Fullah says it's a good thing that Fontas isn't there as Ward is coming home now in a terrible rage.

Fullah: Who? your husband, surely. $\mathrm{He}$ is in a fit again.

Hetook out my husband and kept on insulting marriage and the married and well as all women. Thank God, the fat Pasha isn't here.

(My trans.,Merry Wives, Act II, S.3)

Fontas declares that he is not going to hide in the laundry basket again so the two women suggest to disguise him as the fat aunt of Zahrah's maid. He agrees; what he doesn't know is that Ward hates the maid's fat aunt and has barred her from coming to his home. She is said to be a witch.

Zahrah: I hope my husband will see him dressed like that. $\mathrm{He}$ abhors such an exorcising host. He vowed he would beat them well till their ghosts are out. 


\section{Shakespeare's Merry Wives of Windsor in an Egyptian}

Adaptation:A Study in Cultural Appropriation

(My trans.,Merry Wives, Act II, S.3)

Zahrah decides to fool Ward by putting the laundry basket in front of him, so that he will take time searching through it till Fontas can put on his disguise. Searching the laundry basket, Ward did not find Fontas. Fullah enters with the disguised Fontas. Ward gives the 'aunt' a thrashing. Fontas is forced to act and talk as a woman, swearing to Ward that 'she' will never set foot in his house again.

Fontas (singing in a woman's voice):

I regret. I regret. Came over.

(My trans.,Merry Wives, Act I, S.3)

Zahrah asked the disguised Fontas if he is going to stop chasing flowers, implicitly meaning Fullah and Zahrah, but he answers:

Never love jasmine any more?

Never flirt roses and their blossom?

No, surely no. I beg your pardon.

I'll never do the return.

I've regretted all of it.

(My trans.,Merry Wives, Act II, S.3)

Zahrah and Fullah are pleased with the success of their plan. They decide to tell their husbands all about their schemes to convince them that they are honorable. Ward apologizes to his wife Zahrah, asking her to forgive him, declaring that he will never doubt her again. 


\section{Dr. Hoda Soliman Mohammed}

Ward: Forgiveness, dear wife. Jealousy is a blind devil raising doubts against the noblest .

I can't atone it.

(My trans.,Merry Wives, Act II, S.4)

Zahrah starts to think of a new scheme to humiliate Fontas.

She comes up with a mythical folktale about a water-carrier whose water turns into gold and diamonds.

Zahrah: Simply, we have a popular tale on day ten of

this month. When festival is over, a jin

(a ghost) rides round on a mule calling out

"I'm the water-beaver, water, water."

Lucky one hears him and opens the door welcoming him in for water, in the morning, this water turns into gold and diamond.

Fullah: This is why we've sent lahloobah for the Pasha to pretend to be a mule and visit Ward's house.

Zahrah: once I hear chimes, I open the door pretending to get nature, At this points Afreets (ghosts) attack.

Fullah: Afreets! I like them not .

Zahrah: Not real ones. Nourah will act an Afreet, with other Little girls then attack him. They will ask "whotroubles them?" If a jin kill him, if a human being, he has to reveal his identity and a tone for his guilts. At this point, he will show up and we'll enter with lanterns and candles tarring and feathering him throughout ma'adi.

(My trans.,Merry Wives, Act II, S.3) 


\section{Shakespeare's Merry Wives of Windsor in an Egyptian}

Adaptation:A Study in Cultural Appropriation

Cultural adaptation and appropriation are clear not only in the use of folktale - using folktales from different cultures is common in adaptations - but also in the characters' readiness to believe in the truth of the myth, demonstrating a culture still dominated by superstition.

The final scene shows Fontas, disguised as the She-Mule, enters Ward's house garden. Dr. Ghadban and the dancers tie Fontas up, asking him to admit, who is he and why he is here? In the confusion, Saadoun and Nourah elope.

Fontas recognizes Ward as 'Mabrook' but Ward reveals his identity as Zahrah's husband Ward. Fontas is shocked. Ramady reveals the truth to Fontas, declaring that they are going to humiliate him in public. Fontas begs them to forgive him.

Ward: Shut up. I have your horses in custody , just repaying

your debts to Mabrook. Now, walk out.

(My trans.,Merry Wives, Act II, S.6)

Saadoon enters with Nourah, now his wife, asking her parents to forgive them. Culturally, of course marriage can take place in a few moments in Arab culture, with the presence of a religious cleric to tie the knot, which makes this ruse easy to believe. Ramady and Fullah are humiliated in Fontas' presence when they discover that Nourah has married neither of their choices for her husband. Ward declares that deception is usuful here, in the case of Fontas as it reveals his identity confirming Zahrah's honor, and leads to the unity of Saadoon and Nourah under the authority of love. In the traditional comic happy ending, they all 


\section{Dr. Hoda Soliman Mohammed}

decide to celebrate this evening before dismissing Fontas from Maadi.

Ward ends the play with an ironic line, thanking Fontas as his alter ego Mabrook. Fontas promised him that he would spend that night in Zahrah's bed, and now it has come true. Ward: I have to convey Mabrook's message of thanking as he will really sleep with Zahrah tonight. (My trans.,Merry Wives, Act II, S.6)

The play ends happily, singers and dancers enter. A dancer sings:

Joy, Joy, people of ma'adi, the pasha will leave tonight. A silly man, really silly, while people ride over him and scream. 
Shakespeare's Merry Wives of Windsor in an Egyptian Adaptation:A Study in Cultural Appropriation

ELLS Vol.x No.I (184) December 2016




\section{Dr. Hoda Soliman Mohammed}

\section{Works Cited}

Allen, Graham. Intertextuality, Routledge, London, 2000.

Burroughs, William S. Screenwriting and Potentials of cinema. 1991. In Cohen 1991, Pp.53-86.

Clark, Sandra. The Merry Wives of Windsor Essay. Study Guide, Critical Essays, Vol.3, 1987.

Cohen, Keith, ed. Writing in a film age: Essays by contemporary novelists. Niwot, CO: University Press of Colorado. 1991.

Cohen, Walter. " The Merry Wives of Windsor", Norton Shakespeare, Ed. Stephen Greenblatt. New York:W.W. Norton \& Co., 1997. Pp. 1225-1233.

Gajowoski, Evelyn and Rackin, Phyllis. The Merry Wives of Windsor, New Critical Essays. Routledge, London.2015.

Gilbert, Allan. "The Merry Wives of Windsor." In The Principles and Practice of Criticism : Othello, The Merry Wives, Hamlet,pp.67-93. Detroit: Wayne State University Press, 1959.

Hutcheon, Linda and O'Flynn, Siobhan. A Theory of Adaptation. Second Edition, Routledge, Taylor \& Francis Group, London And New York, 2013.

Jackson, Russell. Reviewed Kavanough, Rachel,Royal Shakespeare Company Production of the Merry Wives of Windsor and notes its Post World War 11 setting, 2003.

Maurice Morgan, Esquire. The Dramatic Characters of Sir John Falstaff, 1777.Cited in Gilbert, Allan. "The Merry Wives of Windsor." In The Principles and Practice of Criticism : Othello, 


\section{Shakespeare's Merry Wives of Windsor in an Egyptian}

Adaptation:A Study in Cultural Appropriation

The Merry Wives, Hamlet,pp.67-93. Detroit: Wayne State University Press, 1959.

Pullman,Philip."Let'sPretend."

https://www.theguardian.com/stage/2004/nov/24/theatre.film

Rowe, Nicholas \& etal. Epistle to the comical Gallant, The Works of Mr. William Shakespeare;: In Six Volumes, Gray-Inn Gate, next Grays- Inn Lane, London, 1709.

Sanders, Julie. Adaptation and Appropriation, International Ltd, Padstow, Cornwall, Great Britian, 2006.

Shakespeare, William. Merry Wives of Windsor, Cambridge University Press, Cambridge, England,1597.

Shurgot, Michael W.. reviewed Grag, Lillian, Oregon Shakespeare Festival Production of Merry Wives of Windsor. 2001.

Uhry, Alfred. Cited in Hutcheon, Linda and O'Flynn, Siobhan. A Theory of Adaptation. Second Edition, Routledge, Taylor \& Francis Group, London And New York, 2013. P. VI

Wimsatt, William K., Jr. Genesis: An Argument Resumed. In Day of the Leopards. New Haven, CT: Yale University Press, 1976, Pp 11-12.

Weimann, Robert. 'Text, Author-Function, and Appropriation in Modern Narrative: Toward a Sociology of Representation', Critical Inquiry, 1988,P.433. 


\section{Dr. Hoda Soliman Mohammed}

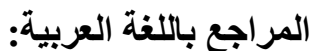

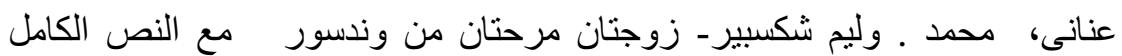

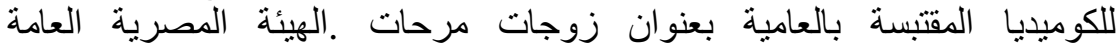

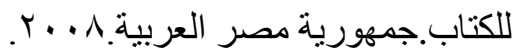

محمود،جيهان.حوار مع محمد محمد عنانى. جريدة الاهر ام للاخبار،جمهورية مصر

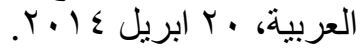

ELLS Vol.x No.I (187) December 2016


Shakespeare's Merry Wives of Windsor in an Egyptian Adaptation:A Study in Cultural Appropriation

ELLS Vol.x No.I (188) December 2016

